\title{
Comparison of chemical, microbiological and histological changes in fresh, frozen and double frozen rainbow trout (Oncorhynchus mykiss)
}

\author{
Peter Popelka ${ }^{1}$, Jozef Nagy ${ }^{1}$, Monika Pipová1, Slavomír Marcinčák ${ }^{1}$, Ludovít Lenhardt² \\ University of Veterinary Medicine and Pharmacy in Košice, ${ }^{1}$ Department of Food Hygiene and Technology, \\ ${ }^{2}$ Department of Pathological Anatomy and Pathological Physiology, Košice, Slovak Republic
}

Received April 4, 2013

Accepted January 23, 2014

\begin{abstract}
The final quality of fish meat depends on the chemical and microbiological quality of fish at the time of freezing as well as on other factors including storage temperature and freezing rate. Analysis of chemical composition (water, protein and fat content), expressible drip, total volatile nitrogen levels, microbiological analyses (total viable counts, Enterobacteriaceae, psychrotrophic bacteria) and histological examinations on dorsal skeletal muscles were carried out to distinguish fresh, frozen and double frozen rainbow trout (Oncorhynchus mykiss). Significantly higher expressible drip and total volatile base nitrogen concentrations $(P<0.05)$ were observed in frozen and double frozen trout, whereas chemical composition of fresh fish muscles was not significantly affected by freezing. The highest total viable counts, counts of Enterobacteriaceae and psychrotrophic bacteria were determined in double frozen trout. The light microscopy of fresh trout muscles did not show any microstructural changes, whereas deformations of muscle fibres and optically empty areas were found in frozen trout. Remarkable defects of the muscle structure in double frozen trout were demonstrated and total disruption of muscle fibres was found. The freezing of trout resulted in various structural changes in the dorsal skeletal musculature. This is a first study comparing changes in fresh, frozen and repeatedly frozen trout. Chemical, microbiological and subsequent histological examinations can be used for revealing the foul practices confusing the consumer with offering thawed fish instead of fresh cooled fish.
\end{abstract}

Chemical composition, freezing, fish, histology, microbiological indicators

Meat products are a large component of human consumption. Their quality is of concern to the consumers, governmental control authorities, and retailers. Nevertheless, meat can be the target of adulteration in many ways, such as illegal sale of thawed instead of fresh meat. Although freezing is an effective method of preserving foods, some deterioration in frozen food quality occurs during storage (Popelka et al. 2012). In the fish industry, the term "fresh" implies that the fish has never been frozen, from the moment of its capture till its distribution among consumers; it is kept chilled until it reaches the final consumer (Ghaly et al. 2010).

Numerous structural and molecular changes take place during frozen storage and freezethaw cycles. Most frequently they include formation of ice crystals resulting in a local increase of salt concentration. The influence of freezing on fish muscle proteins mainly concerns the changes in solubility of protein fractions, their water-holding capacity, and the activity of proteolytic enzymes (Szymczak 2011). Freezing causes disruption and separation of muscle fibre bundles due to the occurrence of numerous extracellular and intracellular ice crystals. Since during freezing muscles undergo changes that include formation of ice crystals and rupture of cell membranes, upon thawing water with soluble components is released from the muscle tissues (Farag et al. 2009). Freezing and thawing operations can significantly influence the quality of frozen foods, particularly in terms of the cellular structure of food.

Address for correspondence:

Peter Popelka

Department of Food Hygiene and Technology

University of Veterinary Medicine and Pharmacy in Košice

Komenského 73,041 81 Košice, Slovakia

Phone: +421905 110774

E-mail: popelkap@lycos.com

http://actavet.vfu.cz/ 
The aim of this study was to determine the basic chemical composition (water, protein and fat content), expressible drip, total volatile base nitrogen (TVB-N) concentrations, and microbiological indicators in the muscles of rainbow trout. Histological changes in the muscle tissues of fresh, frozen and double frozen trout were also monitored.

\section{Materials and Methods}

Sampling

Thirty-six rainbow trout (Oncorhynchus mykiss) were raised at the fish farm Rybarstvo Požehy (Slovak Republic). Fish with an average body weight of $300 \mathrm{~g}$ were eviscerated, washed, vacuum packaged to avoid surface dehydration and cooled. Fish were subjected to 3 different treatments with 12 fish in each group. The first control group was placed directly into the cold room $\left(0-2{ }^{\circ} \mathrm{C}\right)$ and stored for 3 days. Fish from the second group were individually quick frozen (IQF) using the Jet Freezer CT 2392 (Carnitech, Denmark). The system has a unique flow based on air impingement when the fish were placed on a steel belt and the product was led into the freezer where fans circulated air at a temperature below $-35^{\circ} \mathrm{C}$. The fillets were frozen for $20 \mathrm{~min}$ until the temperature of the fish cores reached $-18{ }^{\circ} \mathrm{C}$. The third group (double frozen) was frozen using the same method as in the second group and stored at $-18^{\circ} \mathrm{C}$ for 3 days. Then, the samples were thawed in cold conditions $\left(0-2{ }^{\circ} \mathrm{C}\right)$ until the fish cores reached $-1{ }^{\circ} \mathrm{C}$ and after re-freezing stored again at $-18{ }^{\circ} \mathrm{C}$ for 5 days. The process in the second and third group was completed with thawing at room temperature $\left(21^{\circ} \mathrm{C}\right)$ until the fish cores reached $-1^{\circ} \mathrm{C}$.

\section{Analysis}

Basic chemical indicators, expressible drip, total volatile base nitrogen values, microbiological indicators and histological examination of fresh rainbow trout (first control group) were performed within 3 days of their refrigerating storage. Frozen samples (second group) were examined after 8 days of storage and subsequent thawing and double frozen samples (third group) were examined after their re-freezing and thawing.

Basic chemical composition (water, protein and fat content) was determined according to AOAC Official methods of analysis (2007) and TVB-N values were determined using official steam distillation method according to Commission Regulation (EC) 2074/2005 and expressed as mg TVB-N/100 g rainbow trout flesh. Expressible drip was determined in the muscle samples after 24 -h storage in the refrigerator $\left(+4^{\circ} \mathrm{C}\right)$ using the bag method (Christensen 2003 ).

Samples from the dorsal area of six rainbow trout from each group were taken aseptically to estimate the total viable count (TVC), the count of Enterobacteriaceae, and the count of psychrotrophic bacteria in accordance with the standard procedures (ISO 4833 2003, ISO 21528-2 2004; ISO 6730 2005).

Blocks of muscles $(5 \times 5 \times 5 \mathrm{~mm})$ of 3 rainbow trout from each group were taken from the upper layer of the right dorsal section for light microscopy. Histological examinations included the preparation of paraffin sections (longitudinal and transversal) and their staining using the haematoxylin-eosin method. The samples were photographed under a light microscope (Jenamed 2, Carl Zeiss Jena, × 400).

\section{Statistical analysis}

The mean values and standard deviations were calculated using column statistics with the processing of 6 values for each analyzed group. Significant differences between groups were calculated using one-way ANOVA analysis by Tukey comparative test in the program GraphPad Prism 5 (2007). Differences were evaluated as significant when $P$ value was $<0.05$.

\section{Results}

Results of chemical composition, expressible drip and TVB-N values in samples of rainbow trout are shown in Table 1 . There was no significant difference $(P>0.05)$ in

Table 1. Basic chemical composition, expressible drip and total volatile base nitrogen concentrations in the muscles of rainbow trout.

\begin{tabular}{lccccc}
\hline Sample & $\begin{array}{c}\text { Water content } \\
(\%)\end{array}$ & $\begin{array}{c}\text { Protein content } \\
(\%)\end{array}$ & $\begin{array}{c}\text { Fat content } \\
(\%)\end{array}$ & $\begin{array}{c}\text { Expressible drip } \\
(\%)\end{array}$ & $\begin{array}{c}\text { TVB-N } \\
\left(\mathrm{mg}^{\circ} \cdot 100 \mathrm{~g}^{-1}\right)\end{array}$ \\
\hline Fresh & $76.84 \pm 0.58$ & $18.77 \pm 0.46$ & $2.74 \pm 0.62$ & $1.56^{\mathrm{a}} \pm 0.295$ & $16.35^{\mathrm{a}} \pm 1.737$ \\
Frozen & $76.90 \pm 0.81$ & $18.35 \pm 0.66$ & $3.00 \pm 1.11$ & $12.40^{\mathrm{b}} \pm 0.250$ & $18.80^{\mathrm{b}} \pm 1.140$ \\
Double frozen & $77.41 \pm 0.47$ & $18.58 \pm 0.51$ & $2.03 \pm 0.51$ & $12.85^{\mathrm{b}} \pm 0.176$ & $19.21^{\mathrm{b}} \pm 1.010$ \\
\hline
\end{tabular}

Data are expressed as mean \pm standard deviation. TVB-N - total volatile base nitrogen, ${ }^{\mathrm{a}, \mathrm{b}}$ different superscripted letters indicate significant differences $(P<0.05)$ within rows 
water, protein and fat contents between fresh, frozen and double frozen fish. However, significantly higher expressible drip $(P<0.05)$ was recorded in frozen fish $(12.4 \%)$ and double frozen fish $(12.9 \%)$, compared to fresh fish $(1.6 \%)$ and also significantly higher TVB-N concentrations $(P<0.05)$ in frozen and double frozen fish compared to fresh fish.

Initial total viable counts (TVCs) of bacteria in fresh fish were similar to those of frozen fish. The counts of Enterobacteriaceae and psychrotrophic bacteria were even lower in frozen samples compared to fresh samples. Thawing and repeated freezing in double frozen fish samples led to an increase in TVCs, the counts of Enterobacteriaceae and also psychrotrophic bacteria over the period of storage compared to fresh and frozen fish (Table 2).

Table 2. Microbiological indicators in the muscles of rainbow trout.

\begin{tabular}{lccc}
\hline Sample & $\begin{array}{c}\text { TVC } \\
\left(\mathrm{CFU} \cdot \mathrm{g}^{-1}\right)\end{array}$ & $\begin{array}{c}\text { EB } \\
\left(\mathrm{CFU} \cdot \mathrm{g}^{-1}\right)\end{array}$ & $\begin{array}{c}\text { Psychrotrophs } \\
\left(\mathrm{CFU} \cdot \mathrm{g}^{-1}\right)\end{array}$ \\
\hline Fresh & $1.44 \times 10^{2}$ & $9.00 \times 10^{1}$ & $1.96 \times 10^{3}$ \\
Frozen & $1.48 \times 10^{2}$ & $3.20 \times 10^{1}$ & $3.46 \times 10^{2}$ \\
Double frozen & $3.82 \times 10^{2}$ & $1.12 \times 10^{2}$ & $3.68 \times 10^{3}$ \\
\hline
\end{tabular}

TVC - total viable count, EB - Enterobacteriaceae, CFU colony forming unit

Muscle cells of fresh fish demonstrated only minimal variation of microstructural changes caused by sample processing. No remarkable histological changes were observed in both longitudinal and transversal sections of individual muscles fibres (Plate III, Fig. 1).

In sections obtained from frozen fish, mild damages of muscle fibres were demonstrated, which can be seen in optically low areas in the course of fibres (Plate III, Fig. 2).

Remarkable defects in the muscle structure were demonstrated by optically empty areas in the course of muscle fibres. Fig. 3A (Plate III) shows places with destruction of muscle fibres and perimysium in muscle cells released from muscle fibres. Intense damage of muscle fibre structure and total disruption of muscle fibres is also visible. Based on this observation it can be stated that double freezing of fish significantly damaged the muscle structure (Plate III, Fig. 3B).

\section{Discussion}

Fish meat consists of water, proteins and other nitrogenous compounds, lipids, carbohydrates, vitamins and minerals. Fish meat ranges among the most important sources of proteins of animal origin. Protein content in fish varies from $15 \%$ to $27 \%$ depending on the species. There are also differences in the fat content among fish species, with a fat content below $2 \%$ in the Gadidae, a moderate fat content of $2-10 \%$ in salmon, trout and carp, and with a fat content above $10 \%$ in mackerel and herring. Arannilewa et al. (2005) investigated the effect of freeze storage duration on the chemical, microbiological and sensorial profile of tilapia fish (Sarotherodun galiaenus). In comparison to our results, they reported a decrease in the values of protein and fat by $27.9 \%$ and $2.9 \%$, respectively.

As reported by Simeonidou et al. (1997), frozen Mediterranean hake showed initial expressible water scores of $12.5 \%$ for whole fish and $20.4 \%$ for fillets, which is comparable with the results of our study. After 12 months of frozen storage, they found that expressible water scores significantly increased to $38.1 \%$ for whole fish and $42.9 \%$ for fillets. This increase of expressible water during 12 months of storage could be caused by reduction of the water-holding capacity of fish muscle since muscle proteins are denatured during freezing and thawing.

Post mortem spoilage of food products can be caused by chemical, enzymatic or microbial activities and is accompanied by the formation of compounds responsible for changes in odour, flavour and texture of fish meat. One of the chemical markers of spoilage 
in fish is the total volatile basic nitrogen, including ammonia, trimethylamine (TMA) and dimethylamine (DMA), the concentrations of which increase with spoilage by either bacterial or enzymatic degradation. The total volatile basic nitrogen is produced during degradation of proteins and non-protein nitrogenous compounds, mainly as a result of microbial activity (Özogul and Özogul 2000). Commission Regulation (EC) 2074/2005 set the limits for TVB-N in sea fish, however, no limits are available for fresh-water fish. The concentration of 30-35 mg TVB-N/100 g flesh is considered the limit of acceptability for ice-stored cold water fish (Connell 1995). Since TVB-N is produced mainly during bacterial decomposition of fish meat, the higher content of TVC of samples throughout the period of frozen storage could account for higher TVB-N values of rainbow trout. Hence, TVB-N can be used only as an indicator of fitness for consumption rather than as an index of freshness throughout the storage of fish (Rezaei et al. 2008). Initial TVC, the counts of Enterobacteriaceae and psychrotrophic bacteria of trout after catching were similar to those of frozen fish. Thawing and repeated freezing in double frozen fish samples led to an increase in TVCs, Enterobacteriaceae and also psychrotrophic bacteria. If $10^{6}$ microorganisms $\cdot \mathrm{g}^{-1}$ are considered the TVC limit of acceptability (Özogul et al. 2005), the TVCs in all fish groups examined in our study were deeply below this limit.

It has been stated that the muscle structure of whole fresh muscle changes during freezing and frozen storage due to the shrinking of muscle fibres resulting from the movement of water into extracellular spaces. Therefore, refrozen samples were much less able to retain water during thawing. Thawing, refreezing and subsequent storage may therefore reduce mechanical resistance, rendering fish muscle more susceptible to deterioration during processing. Transversal sections of muscle fibres from both fresh and frozen salmon divided into three groups were performed by Sigurgisladóttir et al. (2000). In their study, the fibres were affected by freezing, frozen storage and/or thawing in all the three groups. The effect of freezing on the transverse microstructure of salmon fillets was mainly seen as enlarged extracellular space between meat fibres. Moreover, some disrupted and shrunken cells could be seen in the frozen/thawed fish, while the cells from the fresh fish seemed to have no fissures. Based on the results obtained from histological examination of fish muscle tissues it may be concluded that double freezing of fish damages the structure of fish muscle tissues. Since freezing and subsequent storage leads to irreversible histological changes in muscle tissues, most frozen-thawed fish have much lower market price compared to fresh fish.

\section{Acknowledgments}

This work was supported by The Ministry of Education, Science, Research and Sports of the Slovak Republic in the framework of the grant VEGA no. 1/0067/13.

\section{References}

AOAC 2007: Official methods of analysis, Gaithersburg, Maryland, USA, Secs. 937.07, 950.46, 960.39, 928.08

Arannilewa ST, Salawu SO, Sorungbe AA, Ola-Salawu BB 2005: Effect of frozen period on the chemical, microbiological and sensory quality of frozen tilapia fish (Sarotherodun galiaenus). Afr J Biotechnol 4: 852855

Christensen LB 2003: Drip loss sampling in porcine $m$. longissimus dorsi. Meat Sci 63: 469-477

Commission Regulation (EC) No 2074/2005 laying down implementing measures for certain products under Regulation (EC) No 853/2004 and for the organisation of official controls under Regulation (EC) No 854/2004 and Regulation (EC) No 882/2004, Official Journal of the European Union L 338

Connell JJ 1995: Control of fish quality (4th ed.). Fishing News Books Limited, London

Farag KW, Duggan E, Morgan DJ, Cronin DA, Lyng JG 2009: A comparison of conventional and radio frequency defrosting of lean beef meats: Effects on water binding characteristics. Meat Sci 83: 278-284

Ghaly AE, Dave D, Budge S, Brooks MS 2010: Fish spoilage mechanisms and preservation techniques: Review. Am J Appl Sci 7: 859-877

ISO 4833 2003: Microbiology of food and animal feeding stuffs. Horizontal method for the enumeration of microorganisms - Colony-count technique at $30^{\circ} \mathrm{C}$ 
ISO 21528-2 2004: Microbiology of food and animal feeding stuffs - Horizontal methods for the detection and enumeration of Enterobacteriaceae - Part 2: Colony-count method

ISO 6730 2005: Milk. Enumeration of colony-forming units of psychrotrophic microorganisms - Colony-count technique at $6.5^{\circ} \mathrm{C}$

Özogul F, Özogul Y 2000: Comparison of methods used for determination of total volatile basic nitrogen (TVB-N) in rainbow trout (Oncorhynchus mykiss). Turk J Zool 24: 113-120

Özogul Y, Ozyurt G, Özogul F, Kuley E, Polat A 2005: Freshness assessment of European eel (Anguilla anguilla) by sensory, chemical and microbiological methods. Food Chem 92: 745-751

Popelka P, Luptakova O, Marcincak S, Nagy J, Mesarcova L, Nagyova A 2012: The effect of glaze and storage temperature on the quality of frozen mackerel fillets. Acta Vet Brno 81: 397-402

Rezaei M, Hosseini SF, Langrudi HE, Safari R, Hosseini SV 2008: Effect of delayed icing on quality changes of iced rainbow trout (Onchorynchus mykiss). Food Chem 106: 1161-1165

Sigurgisladóttir S, Ingvarsdóttir H, Torrissen OJ, Cardinal M, Hafsteinsson H 2000: Effects of freezing/thawing on the microstructure and the texture of smoked Atlantic salmon (Salmo salar). Food Res Int 33: 857-865

Simeonidou S, Govaris A, Vareltzis K 1997: Effect of frozen storage on the quality of whole fish and fillets of horse mackerel (Trachurus trachurus) and Mediterranean hake (Merluccius mediterraneus). Z Lebensm Unters Forsch A 204: 405-410

Szymczak M 2011: Comparison of physicochemical and sensory changes in fresh and frozen herring (Clupea harrengus L.) during marinating. J Sci Food Agric 91: 68-74 
Plate III

Popelka P. et al.: Comparison ... pp. 157-161

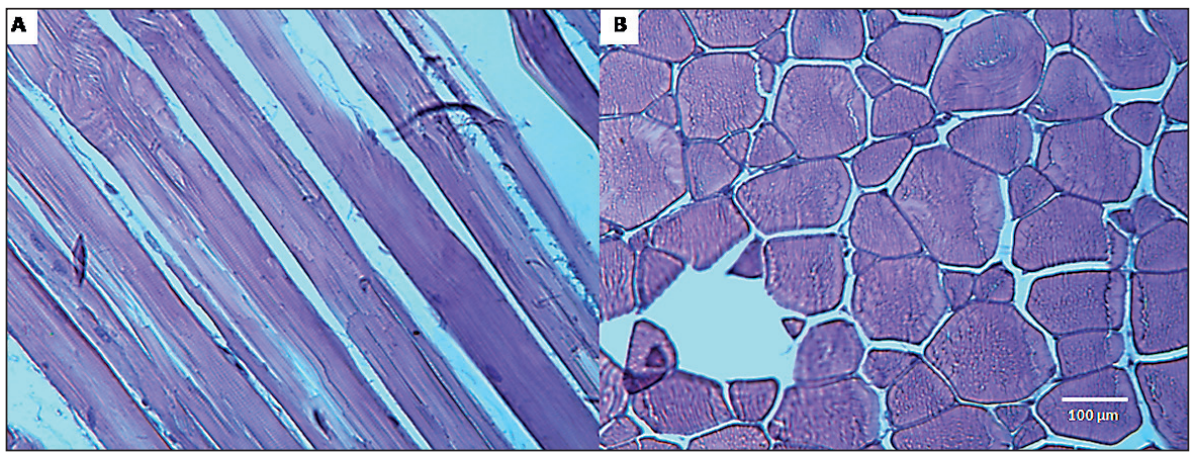

Fig. 1. Longitudinal (A) and transversal (B) section of dorsal muscles of fresh trout $(\times 400$ magnification, scale bar $100 \mu \mathrm{m})$

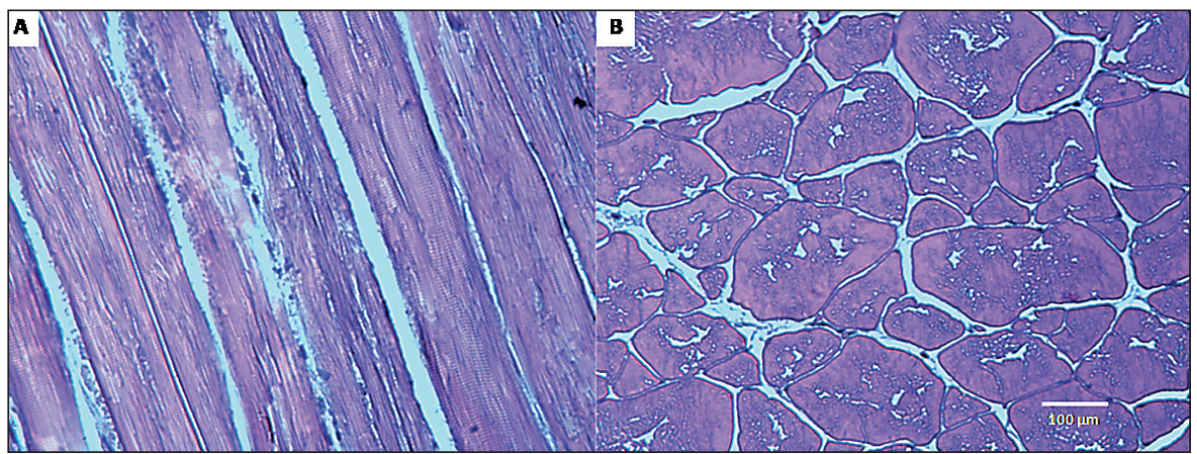

Fig. 2. Longitudinal (A) and transversal (B) section of dorsal muscles of frozen trout $(\times 400$ magnification, scale bar $100 \mu \mathrm{m})$

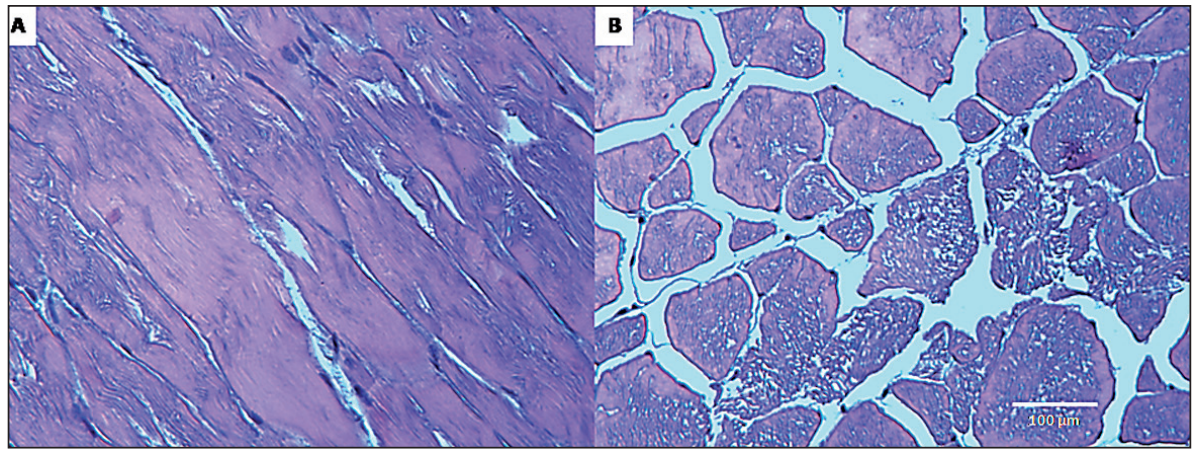

Fig. 3. Longitudinal (A) and transversal (B) section of dorsal muscles of double frozen trout $(\times 400$ magnification, scale bar $100 \mu \mathrm{m})$ 